TATA LOKA

\title{
Analisis Perubahan Penggunaan Lahan dan Prediksinya dengan Menggunakan Markov - Cellular Automata di Wilayah Peri Urban Kota Malang
}

\author{
Landuse Change Analysis and Its Prediction Using Markov-Cellular \\ Automata In Peri Urban Area of Malang City
}

\section{Mirza Permana ${ }^{1}$, Santun R.P Sitorus ${ }^{2}$, dan Darmawan ${ }^{2}$}

\begin{abstract}
Abstrak: Wilayah Peri Urban merupakan wilayah yang unik dengan dinamika keruangan yang terus mengalami perubahan. Delapan kecamatan di wilayah Kabupaten Malang yang berbatasan langsung dengan Kota Malang dan telah mengalami pengaruh yang signifikan terhadap perkembangan kota. Tujuan penelitian adalah mengetahui dinamika perubahan penggunaan lahan dari tahun 2008 - 2018 dan prediksi penggunaan lahan di tahun 2030 serta keselarasannya dengan Rencana Tata Ruang wilayah Kabupaten Malang 2010 - 2030. Metode yang digunakan adalah analisis perubahan penggunaan lahan dari citra landsat TM 8 tahun 2008 dan 2013 untuk memprediksi penggunaan lahan di tahun 2018 yang selanjutnya dilakukan uji validitas untuk mendapatkan tingkat akurasi. Hasil penelitian menunjukkan penggunaan lahan terbangun mengalami kenaikan sebesar $12 \%$ sedangkan lahan pertanian mengalami tren penurunan luasan. Perubahan yang cukup besar terjadi di Kecamatan Singosari, Pakisaji dan Karangploso. Validasi penggunaan lahan antara prediksi tahun 2018 dengan penggunaan lahan aktual tahun 2018 menujukkan nilai kappa cukup tinggi, yakni sebesar $87 \%$. Tren penggunaan lahan di wilayah peri urban hingga tahun 2030 hasil prediksi menunjukkan penggunaan lahan terbangun seluas 26.456 ha yang artinya mengalami kenaikan sebesar 17.686 ha $(33,6 \%)$ dari luas lahan terbangun eksisting tahun 2018. Potensi ketidakselarasan RTRW dengan prediksi penggunaan lahan tahun 2030 sebesar 11.950 ha atau $22,7 \%$.
\end{abstract}

\section{Kata kunci: CA-Markov, perubahan penggunaan lahan, RTRW, wilayah peri urban}

\begin{abstract}
Peri Urban Area is a unique region with spatial dynamics that continues to experience changes that have an important role to play in the urban life in the future. There are 8 sub-districts in Malang Regency which are directly adjacent to Malang City and have a significant influence on the development of the city. Objectives of this research are to determine the dynamics of land use change from 2008 - 2018 and to predict land use in 2030. The method used is the analysis of land use changes from landsat TM 8 images in 2008 and 2013 to predict land use in 2018 which then tested the validity to get a level of accuracy. The results showed the development of built-up area has increased by $12 \%$ while agricultural land has experienced a declining trend. Significant changes occurred in Singosari, Pakisaji and Karangploso sub-district. Validation of land use between the predictions of 2018 and actual land use in 2018 showed that the value of kappa was
\end{abstract}

\footnotetext{
${ }^{1}$ Program Studi Ilmu Perencanaan Wilayah, Sekolah Pascasarjana IPB

${ }^{2}$ Departemen Ilmu Tanah dan Sumberdaya Lahan, Fakultas Pertanian, IPB
} 
quite high, at $87 \%$. The trend of land use in peri-urban areas until the year 2030 is predicted to have built up area of 26,456 ha, which means an increase 17,686 ha (33.6\%) from the existing year 2018. The potential incompatibility of the RTRW with the predicted land use in 2030 is 11,950 ha or $22.7 \%$.

Keywords: CA-Markov, Landuse change, peri-urban area, RTRW

\section{PENDAHULUAN}

Kota sebagai perwujudan ruang geografis yang menampung kegiatan penduduknya akan selalu mengalami pertumbuhan (Hidajat et al. 2013). Berbagai riset menunjukkan bahwa apa yang dikenal sebagai istilah suburban kini menjadi bias/kabur karena adanya penyatuan ruang antara wilayah urban dan pinggirannya. Perembetan aktivitas perkotaan yang terjadi pada wilayah peri urban menyebabkan perubahan pola pemanfaatan lahan akibat beralihnya fungsi pertanian menjadi fungsi perkotaan. Dalam konteks tata ruang, data spasial menunjukkan bahwa wilayah peri urban mengalami percepatan pertumbuhan seiring dengan proses tumbuh kembangnya wilayah kota inti. Kondisi ini dapat dilihat dari dinamika perubahan penggunaan lahan yang dapat didekati dari analisis perubahan tutupan lahan (Ariefin, 2012). Ketersediaan lahan yang relatif tetap akan menyebabkan tingginya kompetisi penggunaan lahan, namun pada akhirnya prioritas perubahan penggunaan lahan akan dimenangkan oleh desakan kebutuhan ekonomi dan sosial (Yudarwati et al. 2016).

Perubahan penggunaan lahan di wilayah peri urban merupakan persoalan yang dilematis. Perubahan tersebut terjadi karena adanya keperluan untuk memenuhi kebutuhan penduduk yang jumlahnya terus bertambah. Kemajuan pembangunan di suatu wilayah sejalan dengan peningkatan jumlah penduduk selalu diiringi dengan peningkatan standar kualitas dan kuantitas kebutuhan hidup, dan peningkatan kebutuhan akan tersedianya berbagai fasilitas yang menyebabkan terjadinya perubahan penggunaan lahan (Sitorus et al. 2012).

Kombinasi antara Geographic Information Systems (GIS) dan CA-Markov merupakan instrumen penting dalam mempelajari dinamika penggunaan lahan. Aplikasi GIS dapat digunakan untuk menganalisis dan melakukan pemetaan dari bentuk perubahan penggunaan lahan secara nyata (Zhang et al. 2002). Konsep dasar analisis markov adalah transisi, dimana transisi diketahui proses berada dalam suatu keadaan tertentu, maka peluang berkembangnya proses di masa mendatang hanya tergantung pada keadaan saat ini dan tidak tergantung pada keadaan sebelumnya. Wilayah pinggiran kota yang rentan terhadap perubahan penggunaan lahan juga menjadi topik yang sering dimodelkan melalui teknik markov, seperti penelitian yang dilakukan Lopez et al. (2001) yang memprediksi perubahan penggunaan lahan di pinggiran kota Morelia, Meksiko.

Perkembangan Kota Malang telah membawa implikasi berkembangnya daerah pinggiran menjadi pusat-pusat permukiman, perdagangan dan industri baru. Sebagai kota terbesar kedua di Jawa Timur setelah Kota Surabaya, Kota Malang memiliki daya tarik bagi penduduk wilayah sekitarnya. Sektor perdagangan menjadi roda penggerak ekonomi utama Kota Malang dengan kontribusi sebesar 29,53\% terhadap PDRB. Berdasarkan data dari BPS Kota Malang Tahun 2017, kepadatan penduduk mencapai $7.453 \mathrm{jiwa} / \mathrm{km}^{2}$.

Secara geografis Kota Malang dikelilingi oleh wilayah Kabupaten Malang. Ada 8 kecamatan di wilayah Kabupaten Malang yang berbatasan langsung dengan Kota Malang dan telah mengalami pengaruh yang signifikan terhadap perkembangan Kota Malang. Delapan kecamatan tersebut meliputi Kecamatan Karangploso, Singosari, Pakis, Tumpang, Tajinan, Pakisaji, Wagir, dan Dau. Kecamatan - kecamatan tersebut sudah lama mengalami proses complementarity dalam pertukaran barang dan jasa dengan Kota Malang. Akses jalan yang baik sangat mendukung interaksi antara Kota Malang dan kecamatan peri urban.

Densifikasi bangunan yang terjadi secara terus menerus dan tidak terkendali dapat menyebabkan terciptanya saturated settlement, yaitu permukiman yang didalamnya tidak terdapat lagi ruang kosong. Studi/kajian tentang peri urban menjadi penting sebagai upaya 
mengantisipasi perkembangan kecamatan peri urban dimasa yang akan datang. Identifikasi dini permasalahan perubahan lingkungan di wilayah peri urban akan memudahkan para pembuat kebijakan dan keputusan mengenai perencanaan pengembangan wilayah untuk menentukan langkah-langkah yang bijak dalam pembangunan wilayah peri urban. Penelitian ini bertujuan untuk mengetahui dinamika perubahan penggunaan lahan dari tahun 2008 - 2018 dan prediksi penggunaan lahan di tahun 2030 serta keselarasannya dengan Rencana Tata Ruang wilayah Kabupaten Malang 2010 - 2030.

\section{METODE}

Penelitian ini dilaksanakan di 8 (delapan) kecamatan di wilayah Kabupaten Malang yang diidentifikasi sebagai wilayah peri urban dari Kota Malang. Delapan kecamatan tersebut adalah: Kecamatan Karangploso, Singosari, Pakis, Tumpang, Tajinan, Pakisaji, Wagir, dan Dau yang disajikan pada Gambar 1. Penelitian ini dilaksanakan pada bulan September 2018 hingga Mei 2019. Keterkaitan antara tujuan penelitian, jenis data, metode analisis, dan hasil yang diharapkan secara ringkas disajikan pada Tabel 1.

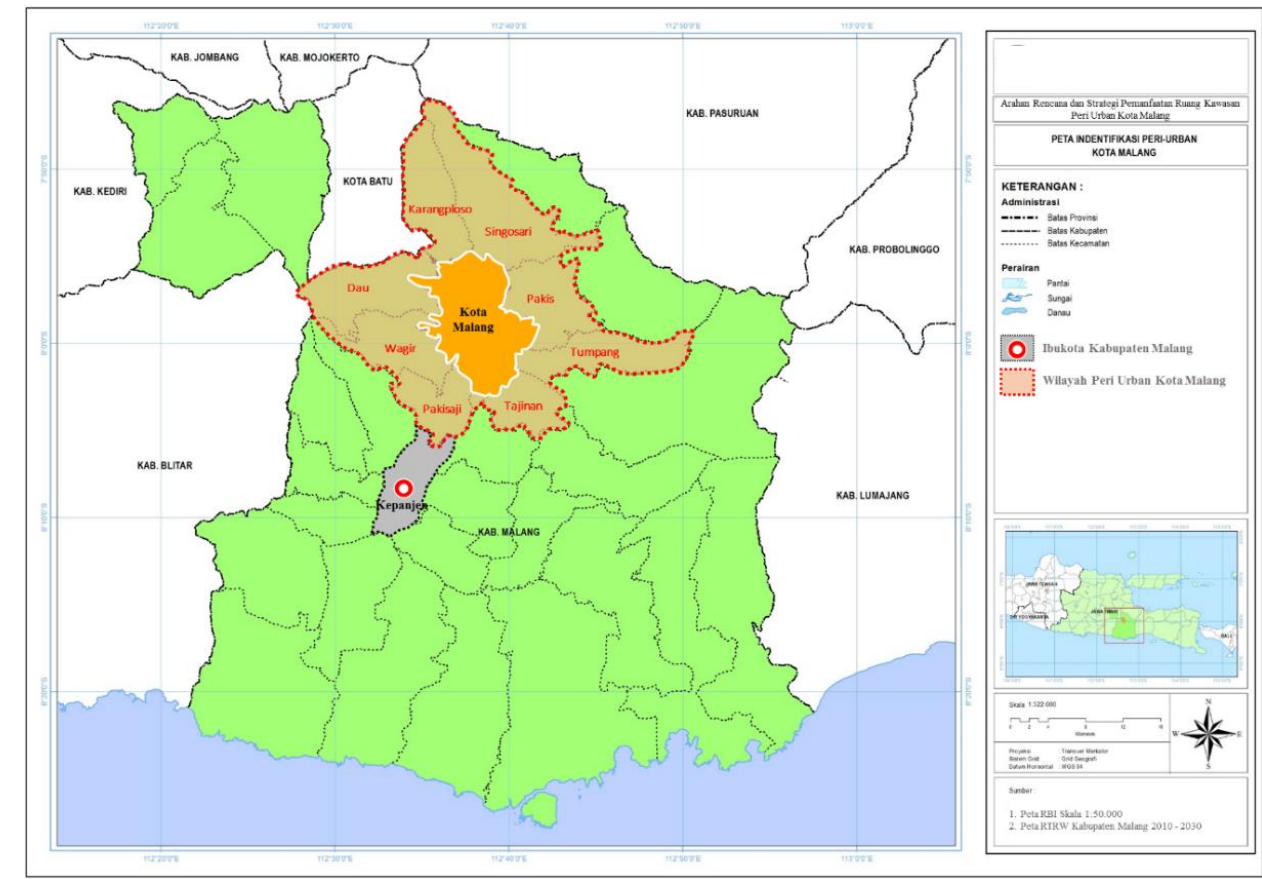

Gambar 1. Peta Lokasi Penelitian

Tabel 1. Matriks Hubungan antara Tujuan, Jenis Data, Metode Analisis dan Hasil

\begin{tabular}{|c|c|c|c|c|}
\hline No & Tujuan & Jenis Data & Metode Analisis & Hasil \\
\hline 1 & $\begin{array}{l}\text { Mengetahui dinamika perubahan } \\
\text { penggunaan lahan di wilayah peri } \\
\text { urban }\end{array}$ & $\begin{array}{l}\text { Peta Penggunaan } \\
\text { Lahan tahun 2008, } \\
2013 \text { dan } 2018\end{array}$ & $\begin{array}{l}\text { Overlay } \\
\text { Analisis } \\
\text { deskriptif }\end{array}$ & $\begin{array}{l}\text { Matriks perubahan } \\
\text { penggunaan lahan dan } \\
\text { sebaran spasialnya }\end{array}$ \\
\hline 2 & $\begin{array}{l}\text { Melakukan prediksi penggunaan } \\
\text { lahan tahun } 2030\end{array}$ & $\begin{array}{l}\text { Peta Penggunaan } \\
\text { Lahan tahun 2008, } \\
2013 \text { dan } 2018\end{array}$ & $\begin{array}{l}\text { Markov } \\
\text { Cellular } \\
\text { Automata }\end{array}$ & $\begin{array}{l}\text { Peta prediksi penggunaan } \\
\text { lahan tahun } 2030\end{array}$ \\
\hline 3 & $\begin{array}{l}\text { Mengevaluasi keselarasan } \\
\text { penggunaan lahan } 2030 \text { dengan } \\
\text { RTRW }\end{array}$ & $\begin{array}{l}\text { Output tujuan } 2 \\
\text { Peta Pola Ruang }\end{array}$ & $\begin{array}{l}\text { Overlay } \\
\text { Analisis } \\
\text { deskriptif }\end{array}$ & $\begin{array}{l}\text { Kesesuaian } \\
\text { penggunaan lahan } \\
\text { dengan RTRW }\end{array}$ \\
\hline
\end{tabular}



berikut:

Teknik analisis data yang digunakan untuk menjawab tujuan penelitian adalah sebagai

\section{Analisis Perubahan Penggunaan Lahan}

Identifikasi perubahan penggunaan lahan pada suatu wilayah merupakan suatu proses mengindentifikasi perbedaan keberadaan suatu objek atau fenomena yang diamati pada waktu yang berbeda (As-syakur et al. 2010). Perubahan penggunaan lahan merupakan suatu bentuk analisis kuantitatif spasial yang diperlukan sebagai acuan untuk tahap analisis selanjutnya. Analisis dilakukan pada peta penggunaan lahan 3 (tiga) titik tahun melalui teknik overlay dengan skala dan attribute peta yang sama sehingga diperoleh matriks transisi dari perubahan penggunaan lahan. Data yang digunakan adalah peta penggunaan lahan tahun 2008 yang bersumber dari Badan Perencanaan Pembangunan (Bappeda) Kabupaten Malang dan interpretasi citra landsat TM 8 tahun 2013 dan 2018. Alur kerja overlay peta penggunaan lahan disajikan pada Gambar 2.

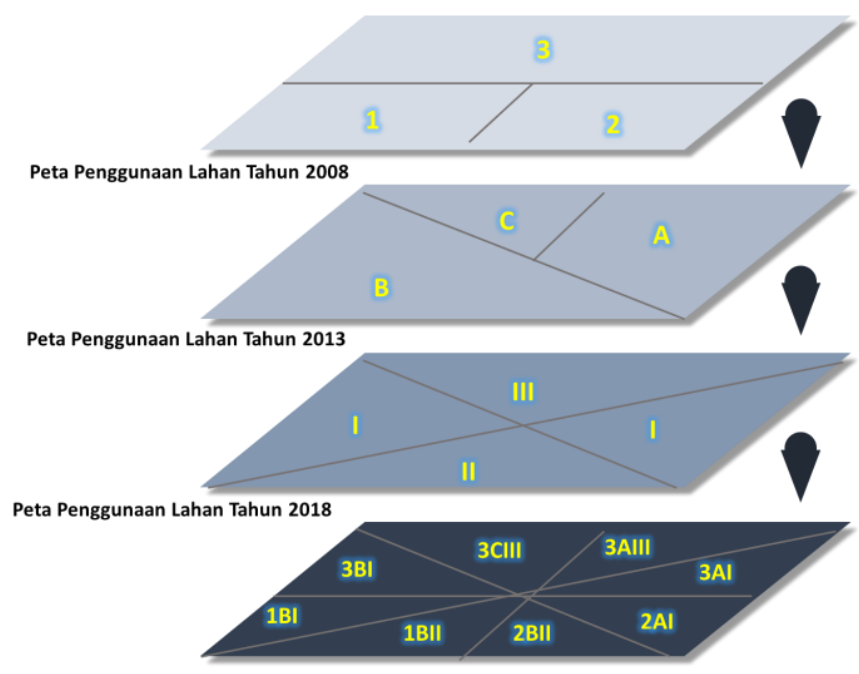

Gambar 2. Alur Kerja Overlay Peta Penggunaan Lahan

\section{Metode Markov Chain - Cellular Automata}

Pemodelan prediksi penggunaan lahan dilakukan dengan pendekatan metode Markov Chain dan Cellular Automata (CA). El-Hallaq dan Habboub (2015) menjelaskan proses Markov Chain sebagai keadaan sistem pada waktu kedua dapat diprediksi dengan keadaan sistem pada waktu pertama dengan memberikan matriks probabilitas transisi dari masing-masing kelas penutupan lahan untuk setiap kelas penutupan lahan lainnya. Model Markov - CA menggunakan filter matriks berukuran 5 x 5 yang merupakan penerjemahan dari konsep ketetanggaan.

Analisis ini dibagi menjadi tiga tahap. Tahap pertama adalah tahap simulasi dalam menentukan penggunaan lahan dua titik tahun yang akan dijadikan dasar prediksi dalam analisis Markov. Berdasarkan asumsi Markov bahwa pola perubahan penggunaan lahan di masa yang akan datang serupa dengan pola perubahan penggunaan lahan masa yang telah lalu (Deng et al. 2009). Untuk mencapai tujuan tersebut perlu dilakukan beberapa tahap analisis simulasi agar model yang digunakan untuk prediksi penggunaan lahan tahun 2030 memiliki nilai akurasi yang baik. Data landuse tahun 2008 di overlay dengan 2013 untuk memproyeksikan landuse tahun 2018. Hasil dari overlay peta tahun 2008 dan 2013 akan menghasilkan matriks peluang 
perubahan penggunaan lahan. Matriks tersebut akan dijadikan dasar dalam memprediksi penggunaan lahan tahun 2018.

Tahap kedua adalah memvalidasi hasil proyeksi dengan peta penggunaan lahan tahun 2018 sehingga menghasilkan nilai Kappa diatas 80\%. Peta penggunaan lahan 2018 yang terkonfirmasi tersebut dianggap sebagai penggunaan lahan aktual.

Tahap ketiga adalah memprediksi penggunaan lahan tahun 2030 berdasarkan penggunaan lahan tahun 2008 dan penggunaan lahan tahun 2013. Hasil prediksi penggunaan lahan tersebut dikonfirmasi dengan Rencana Tata Ruang Wilayah Kabupaten Malang 20102030 sehingga didapat nilai keselarasannya dan dapat diidentifikasi potensi permasalahan tata ruang tahun 2030 berdasarkan hasil prediksi Markov. Ketiga tahap dalam proses analisis ini disajikan secara diagram alir pada Gambar 3.

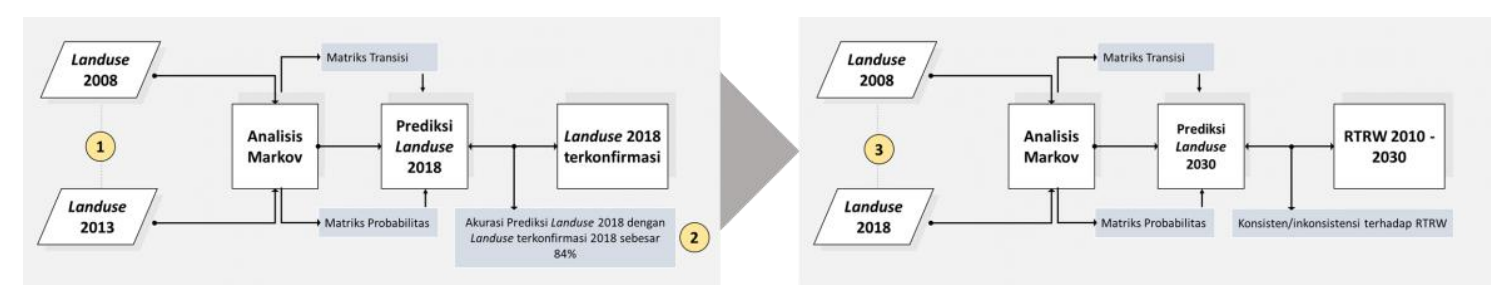

Gambar 3. Diagram Alir Pengujian Prediksi Markov 2018 dan 2030 serta Keselarasannya dengan RTRW

\section{Keselarasan Penggunaan Lahan Tahun 2030 dengan RTRW}

Bentuk inkonsistensi pemanfaatan ruang di wilayah peri urban Kota Malang dapat diketahui dengan tumpang tindih (overlay) peta penggunaan lahan hasil prediksi 2030 dan peta pola ruang RTRW Kabupaten Malang 2010 - 2030. Peta hasil tumpang tindih di-query berdasarkan matrik logik inkonsistensi yang menghasilkan peta inkonsistensi pemanfaatan ruang. Pergeseran penggunaan lahan berlangsung secara searah dan bersifat irreversible (tidak dapat balik), seperti lahan-lahan hutan yang sudah dikonversi menjadi lahan pertanian umumnya sulit dihutankan kembali. Sektor-sektor yang komersial dan strategis mempunyai land rent yang tinggi. Sebaliknya sektor-sektor yang kurang mempunyai nilai komersial nilai land rent-nya semakin kecil (Rustiadi et al. 2011).

\section{HASIL DAN PEMBAHASAN}

\section{Dinamika Perubahan Penggunaan Lahan di Wilayah Peri Urban Kota Malang}

Penggunaan lahan erat kaitannya dengan aktivitas manusia dan sumber daya lahan. Setiap bentuk penggunaan lahan merupakan hasil dari upaya manusia yang sifatnya terus menerus dalam memenuhi kebutuhannya. Penggunaan lahan wilayah peri urban Kota Malang masih didominasi lahan pertanian, baik pertanian lahan kering maupun pertanian lahan basah. Luas lahan pertanian secara keseluruhan yang diusahakan seluas 25.164 ha atau $50 \%$ dari total luas wilayah peri urban. Selain sebagai penyangga kota, keberadaan lahan pertanian di wilayah pinggiran kota sangat penting untuk menghindari kerawanan pangan, kerusakan lingkungan, atau ancaman hilangnya budaya-budaya lokal (Simon, 2008). Persentase luas jenis penggunaan lahan yang lain secara berturut-turut adalah hutan (11\%), permukiman/lahan terbangun (37\%) dan semak belukar (2\%). Pemanfaatan lahan terbangun seperti permukiman, industri dan perdagangan jasa berkembang linear di sepanjang ruas jalan utama.

Hasil overlay peta penggunaan lahan tahun 2008, 2013 dan 2018 menunjukkan luasan lahan terbangun memiliki trend naik sementara luasan kawasan hutan dan lahan pertanian mengalami penurunan seperti yang disajikan pada Tabel 2. Sitorus (2017) mengungkapkan bahwa perubahan/alih fungsi lahan pertanian terjadi karena adanya dorongan orientasi ekonomi 
yang mementingkan keuntungan jangka pendek, tanpa memperhitungkan manfaat yang hilang akibat alih fungsi tersebut. Pergeseran pola penggunaan lahan dari pertanian menjadi non pertanian merupakan bentuk transformasi fisik yang sering ditemui di wilayah peri urban.

Tabel 2. Trend Perubahan Penggunaan Lahan Wilayah Peri Urban

\begin{tabular}{|c|c|c|c|}
\hline \multirow{2}{*}{ Jenis Penggunaan Lahan } & \multicolumn{3}{|c|}{ Luas (ha) } \\
\hline & 2008 & 2013 & 2018 \\
\hline Sungai/Badan Air & 39 & 39 & 39 \\
\hline Semak Belukar & 2146 & 2147 & 3086 \\
\hline Hutan & 3403 & 3403 & 2458 \\
\hline Sawah irigasi & 17223 & 16998 & 16670 \\
\hline Sawah Tadah Hujan & 41 & 41 & 41 \\
\hline Kebun/ Ladang & 21046 & 20912 & 20165 \\
\hline Terbangun & 8770 & 9129 & 10209 \\
\hline Jumlah & 52668 & 52668 & 52668 \\
\hline
\end{tabular}

Alih fungsi lahan pertanian menjadi lahan non pertanian merupakan fenomena yang sulit dihindarkan di wilayah peri urban. Selama 10 tahun perkembangan lahan terbangun mengalami kenaikan sebesar 12\% sebagaimana tersaji pada Tabel 3 dan Gambar 4.

Tabel 3. Perkembangan Penggunaan Lahan Terbangun dan Non Terbangun di Wilayah Peri Urban

\begin{tabular}{cccccccc}
\hline \multirow{2}{*}{ No } & Penggunaan Lahan & \multicolumn{2}{c}{ Tahun 2008 } & \multicolumn{2}{c}{ Tahun 2013 } & \multicolumn{2}{c}{ Tahun 2018 } \\
\cline { 3 - 7 } & Wilayah Peri Urban & (WPU) & ha & \% & ha & \multirow{2}{*}{ \% } & \multirow{2}{*}{ ha } \\
\hline \multirow{2}{*}{1} & Terbangun & 8.639 & 17 & 11.578 & 22 & 14.773 \\
2 & Non Terbangun & 44.038 & 83 & 41.099 & 78 & 37.904 \\
\hline
\end{tabular}

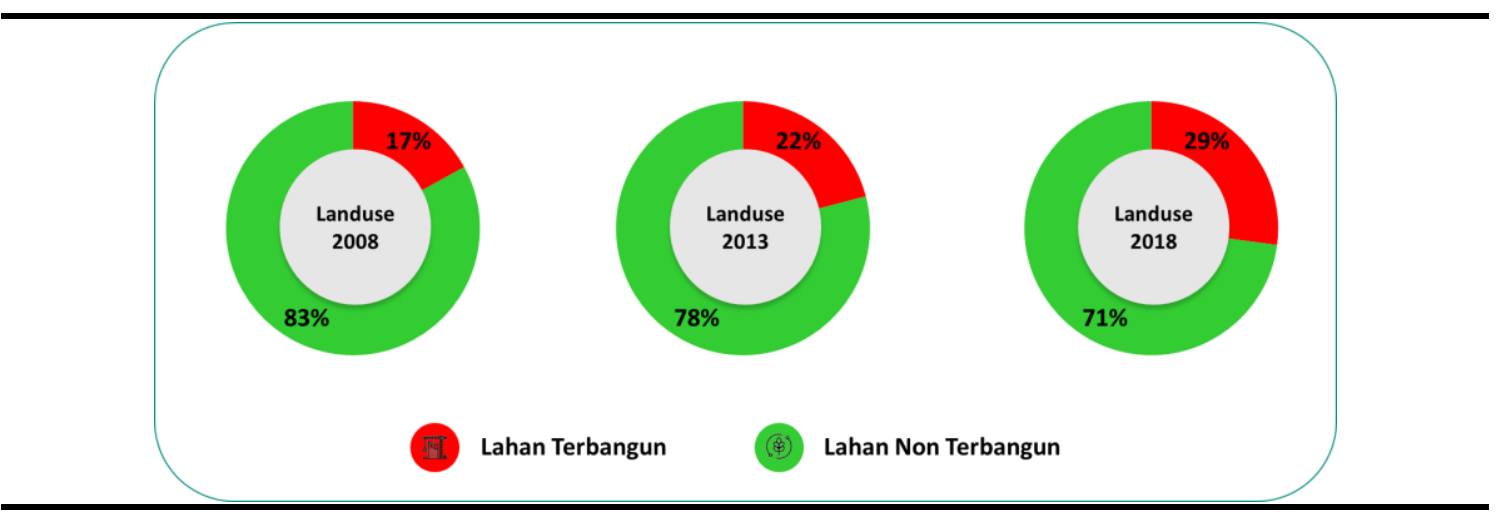

Gambar 4. Perbandingan Penggunaan Lahan di WPU Tahun 2008, 2013 dan 2018

Proses perubahan penggunaan lahan bersifat historis yang mengikuti arah perkembangan Kota Malang, sebagaimana yang ditulis Pradoto dan Mahendra (2016). Perkembangan wilayah di utara kota mengalami pertumbuhan yang lebih cepat dibandingkan dengan selatan sebagaimana disajikan pada Gambar 5.

Polarisasi pembangunan pada Kota Malang dan Kota Surabaya merupakan proses urbanisasi yang berkaitan erat dengan perkembangan investasi di bidang industri manufaktur yang berskalarorientasi ekspor. Faktor inilah yang memacu pertumbuhan koridor SurabayaMalang. Proses industrialisasi ini telah mengakibatkan perubahan struktur ekonomi wilayah pinggiran mengaburkan batas-batas antara kehidupan perkotaan dan perdesaan, dan meningkatnya peran swasta dalam mengarahkan perkembangan wilayah perkotaan. Muta'ali (1998) mengemukakan bahwa perkembangan pola keruangan penduduk perkotaan di Pulau Jawa memperlihatkan kecenderungan perkembangan pada koridor perkotaan yang menghubungkan kota-kota besar. 


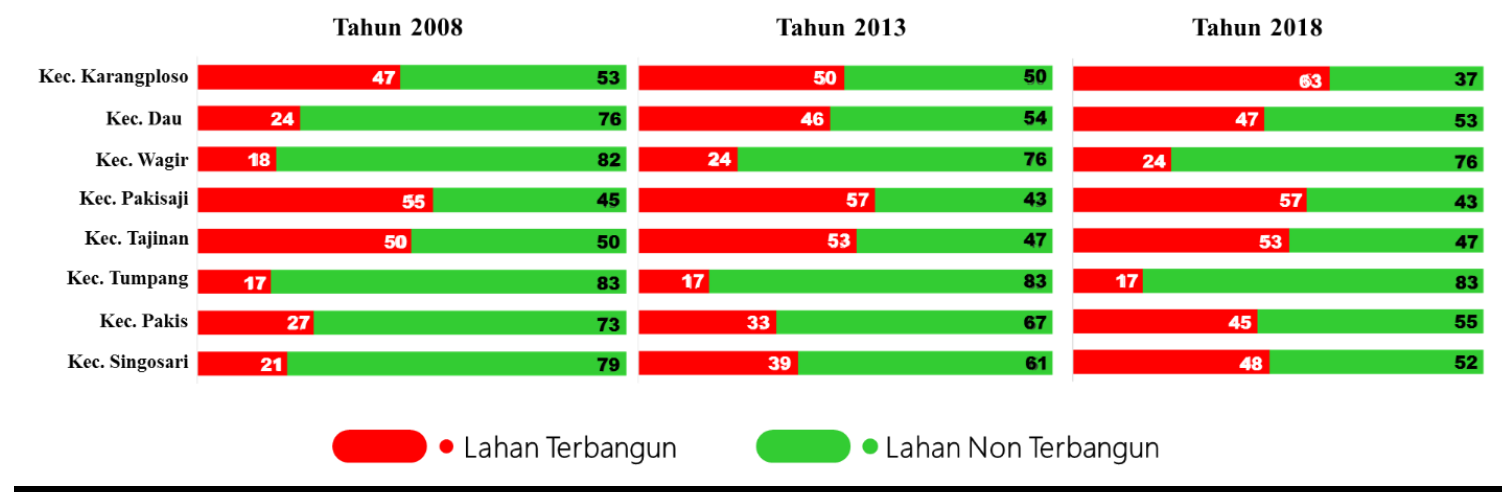

Gambar 5. Persentase Perubahan Penggunaan Lahan di Setiap Kecamatan Peri Urban

Perkembangan fisik wilayah peri urban seolah-olah menyatu dengan pusat kota seperti yang terlihat di Kecamatan Singosari. Letak yang strategis karena berada poros jalan raya Malang-Surabaya menyebabkan beberapa industri besar dan menengah membangun pabriknya di Singosari. Berdasarkan sensus ekonomi tahun 2016 tercatat sebanyak 17.111 usaha/perusahaan berada di Kecamatan Singosari atau 6,54\% dari total perusahaan yang ada di wilayah Kabupaten Malang.

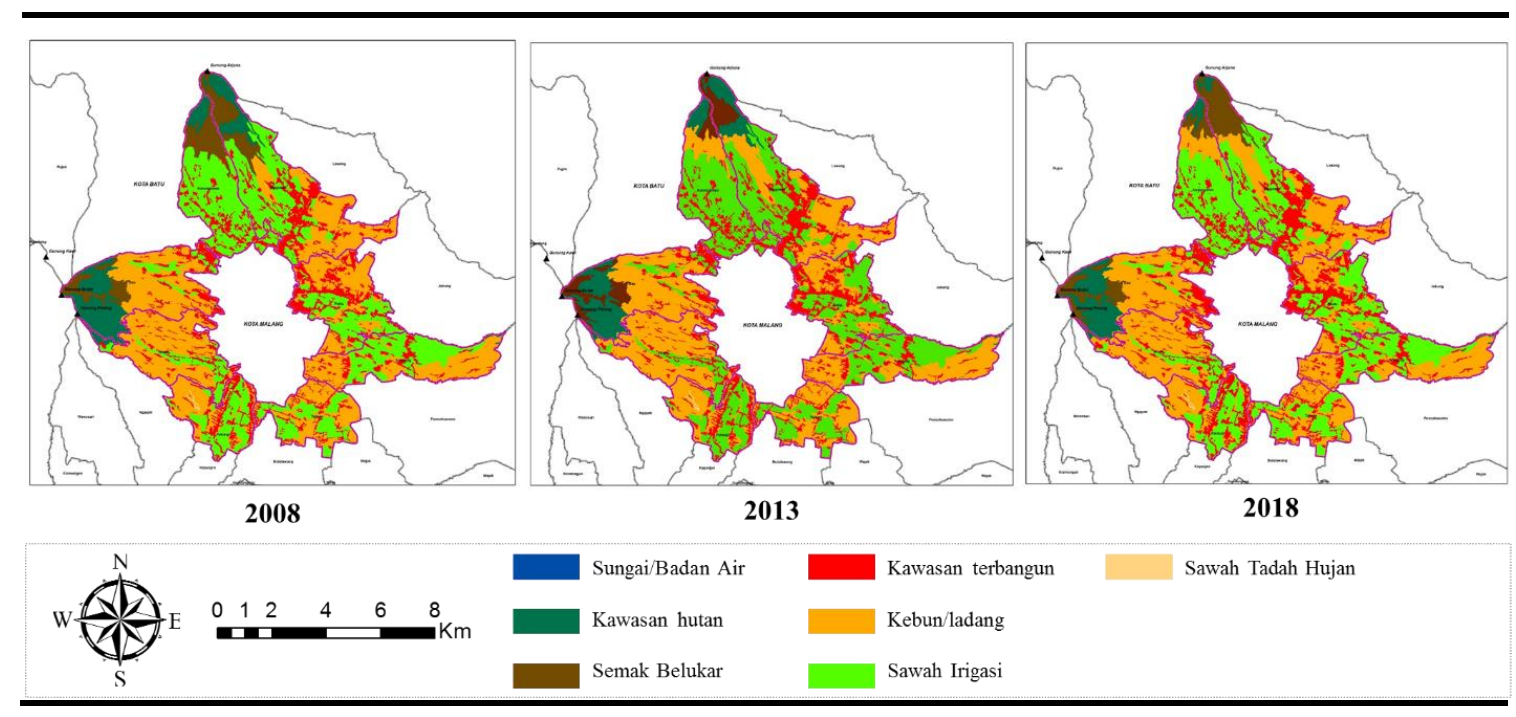

Gambar 6. Sebaran Spasial Penggunaan Lahan Wilayah Peri Urban Kota Malang Tahun 2008, 2013 dan 2018

Aspek kependudukan menjadi faktor penting yang mempengaruhi perubahan penggunaan lahan suatu wilayah. Pertumbuhan penduduk di wilayah peri urban merupakan imbas dari arus urbanisasi yang cukup tinggi ke Kota Malang. Lahan yang bersifat tetap tidak mampu memenuhi kebutuhan penduduk untuk memberikan ruang baru sebagai tempat tinggal dan aktivitas lainnya. Sensus penduduk yang dilakukan pada Tahun 2010 mencatat bahwa jumlah penduduk wilayah peri urban sebesar 733.876 jiwa yang artinya jumlah tersebut hampir menyamai jumlah penduduk Kota Malang yang berjumlah 820.243 jiwa. Berdasarkan data BPS Kabupaten Malang, pada tahun 2018 jumlah penduduk di wilayah peri urban mengalami peningkatan menjadi 827.897 jiwa. Artinya dalam kurun waktu 8 tahun telah terjadi penambahan penduduk sebesar 94.021 jiwa (Gambar 7). 


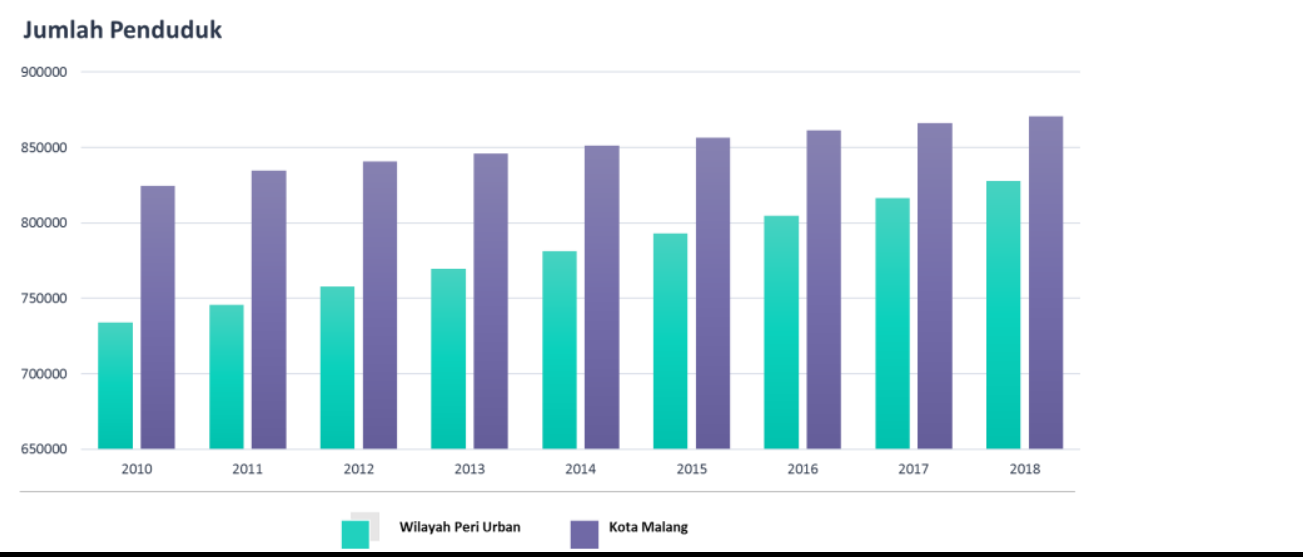

Gambar 7. Perbandingan Jumlah Penduduk Wilayah Peri Urban dengan Kota Malang

\section{Prediksi Penggunaan Lahan Tahun 2030}

Prediksi penggunaan lahan tahun 2030 dilakukan untuk melihat keselarasan maupun ketidakselarasan dengan kebijakan rencana tata ruang wilayah Kabupaten Malang yang telah ditetapkan melalui Peraturan Daerah No. 03 Tahun 2010. Validasi penggunaan lahan antara prediksi tahun 2018 dengan penggunaan lahan aktual tahun 2018 menujukkan nilai kappa cukup tinggi, yakni sebesar $87 \%$. Nilai kappa tersebut membuktikan bahwa model tersebut dapat digunakan dalam memprediksi penggunaan lahan mendatang. Konfirmasi penggunaan lahan prediksi tahun 2018 dengan penggunaan lahan aktual tahun 2018 dapat dilihat pada Gambar 8.

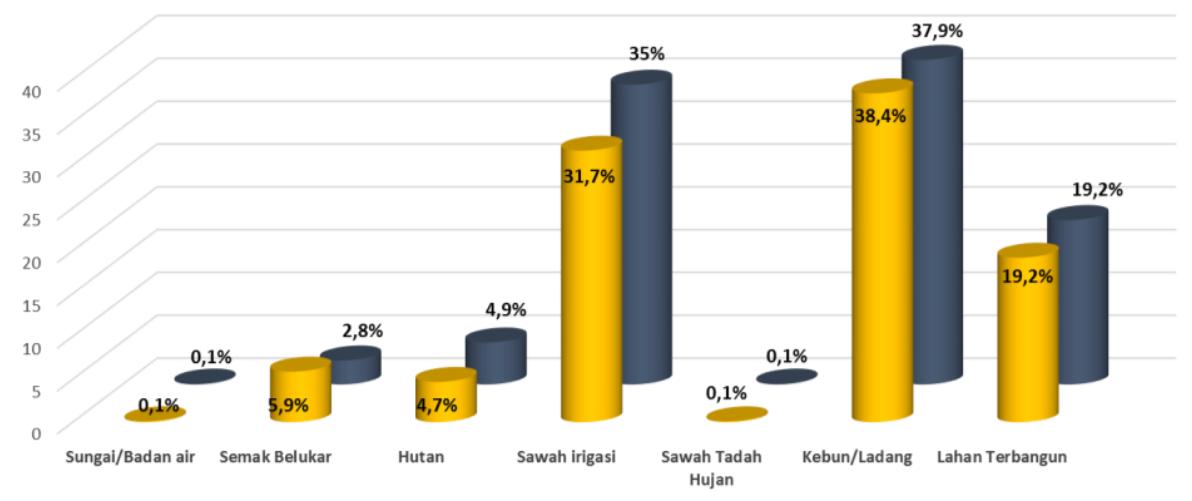

= Penggunaan Lahan aktual 2018 - Penggunaan Lahan Prediksi 2018

Gambar 8. Perbandingan Penggunaan Lahan Tahun 2018 Hasil Prediksi dengan Penggunaan Lahan Aktual Tahun 2018

Selisih terbesar pada kelas penggunaan lahan sawah irigasi, yakni 3,2\% yang lebih besar dari penggunaan lahan aktual. Proyeksi penggunaan lahan tahun - tahun mendatang berdasarkan pada matriks peluang terjadinya perubahan penggunaan lahan antara tahun 2008 - 2013 ataupun 2013 - 2018. Matriks ini menggambarkan peluang terjadinya perubahan dimasa mendatang dengan nilai peluang berkisar dari 0 - 1 sebagaimana tertera pada Tabel 5 .

Pada komponen on-diagonal (kotak biru) nilai yang mendekati 1 berarti penggunaan lahan tersebut berpeluang besar untuk tidak berubah ke penggunaan lahan lainnya. Kotak offdiagonal menunjukkan peluang suatu penggunaan lahan untuk berubah ke penggunaan lahan lainnya. Semakin mendekati 1 , maka semakin besar peluang untuk berubah ke penggunaan 
lahan lainnya. Penggunaan lahan yang mempunyai peluang terbesar untuk berubah ke penggunaan lahan lainnya adalah hutan $(0,7223)$ berpeluang besar berubah menjadi kebun/tegalan dan persawahan $(0,5173)$ berpeluang besar menjadi penggunaan lahan non pertanian atau terbangun.

Table 5. Matriks Peluang Perubahan Penggunaan Lahan Tahun 2008 - 2013

\begin{tabular}{|c|c|c|c|c|c|c|c|}
\hline $\begin{array}{l}\text { Penggunaan } \\
\text { Lahan Tahun } \\
\text { Penggunaan } \\
\text { Lahan Tahun } \\
2008\end{array}$ & Hutan & $\begin{array}{l}\text { Kebun/ } \\
\text { Ladang }\end{array}$ & $\begin{array}{l}\text { Sawah } \\
\text { Irigasi }\end{array}$ & $\begin{array}{l}\text { Sawah } \\
\text { Tadah } \\
\text { Hujan }\end{array}$ & $\begin{array}{c}\text { Semak } \\
\text { Belukar }\end{array}$ & $\begin{array}{c}\text { Sungai/ } \\
\text { Badan Air }\end{array}$ & $\begin{array}{l}\text { Lahan } \\
\text { Terbangun }\end{array}$ \\
\hline Hutan & 0,0000 & 0,7223 & 0,0000 & 0,0000 & 0,2777 & 0,0000 & 0,0000 \\
\hline Kebun/Ladang & 0,0000 & 0,3320 & 0,0000 & 0,0000 & 0,2129 & 0,0000 & 0,4551 \\
\hline Sawah Irigasi & 0,0000 & 0,0333 & 0,4494 & 0,0000 & 0,0000 & 0,0000 & 0,5173 \\
\hline Sawah Tadah Hujan & 0,0000 & 0,0000 & 0,0000 & 0,7185 & 0,0000 & 0,0000 & 0,2815 \\
\hline Semak Belukar & 0,0000 & 0,3779 & 0,0000 & 0,0000 & 0,1365 & 0,0000 & 0,4856 \\
\hline Sungai/Badan Air & 0,0000 & 0,0000 & 0,0000 & 0,0000 & 0,0000 & 1,0000 & 0,0000 \\
\hline Lahan Terbangun & 0,0000 & 0,0000 & 0,0000 & 0,0000 & 0,0000 & 0,0000 & 1,0000 \\
\hline
\end{tabular}

Trend penggunaan lahan di wilayah peri urban cenderung dinamis dan bersifat kekotaan. Berdasarkan hasil prediksi penggunaan lahan pada tahun 2023, 2028 dan 2033 terlihat perkembangan penggunaan lahan terbangun cukup signifikan sebagaimana tersaji pada Gambar 9. Hingga tahun 2033 diprediksi penggunaan lahan terbangun seluas 26.456 ha yang artinya mengalami kenaikan sebesar 17.686 ha $(33,6 \%)$ dari luas lahan terbangun eksisting tahun 2018. Penggunaaan/tutupan lahan berupa hutan, pertanian non sawah, dan sawah cenderung mengalami penurunan sejak tahun 2013. Hal ini sesuai dengan teori land rent yang menjelaskan bahwa perubahan penggunaan lahan akan cenderung menuju ke penggunaan lahan dengan nilai land rent yang lebih tinggi.

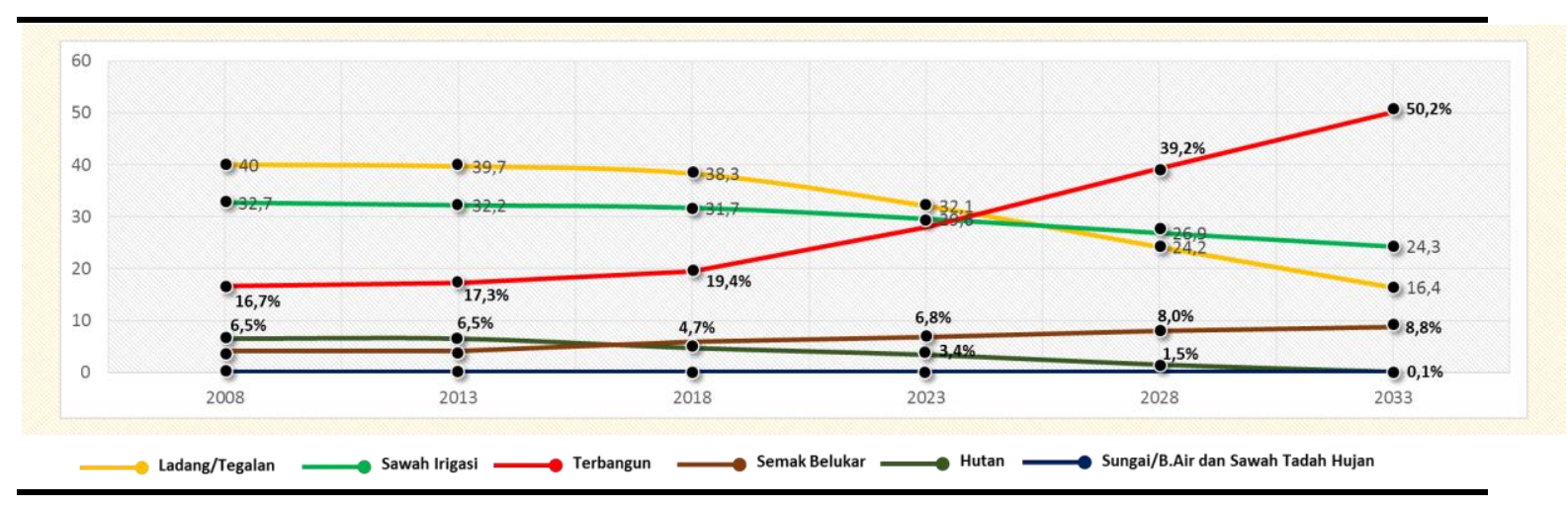

Gambar 9. Trend Penggunaan Lahan Tahun 2008 - 2033

Hasil prediksi menunjukkan luasan pertanian lahan basah (padi sawah) mengalami penyusutan menjadi 12.787 ha. Hasil prediksi penggunaan lahan tahun 2030 sebagaimana yang disajikan pada Gambar 10 dapat dijadikan bahan pertimbangan/acuan guna mengontrol pemanfaatan ruang wilayah peri urban sehingga pengembangan wilayah tetap harmonis dan berkelanjutan. 


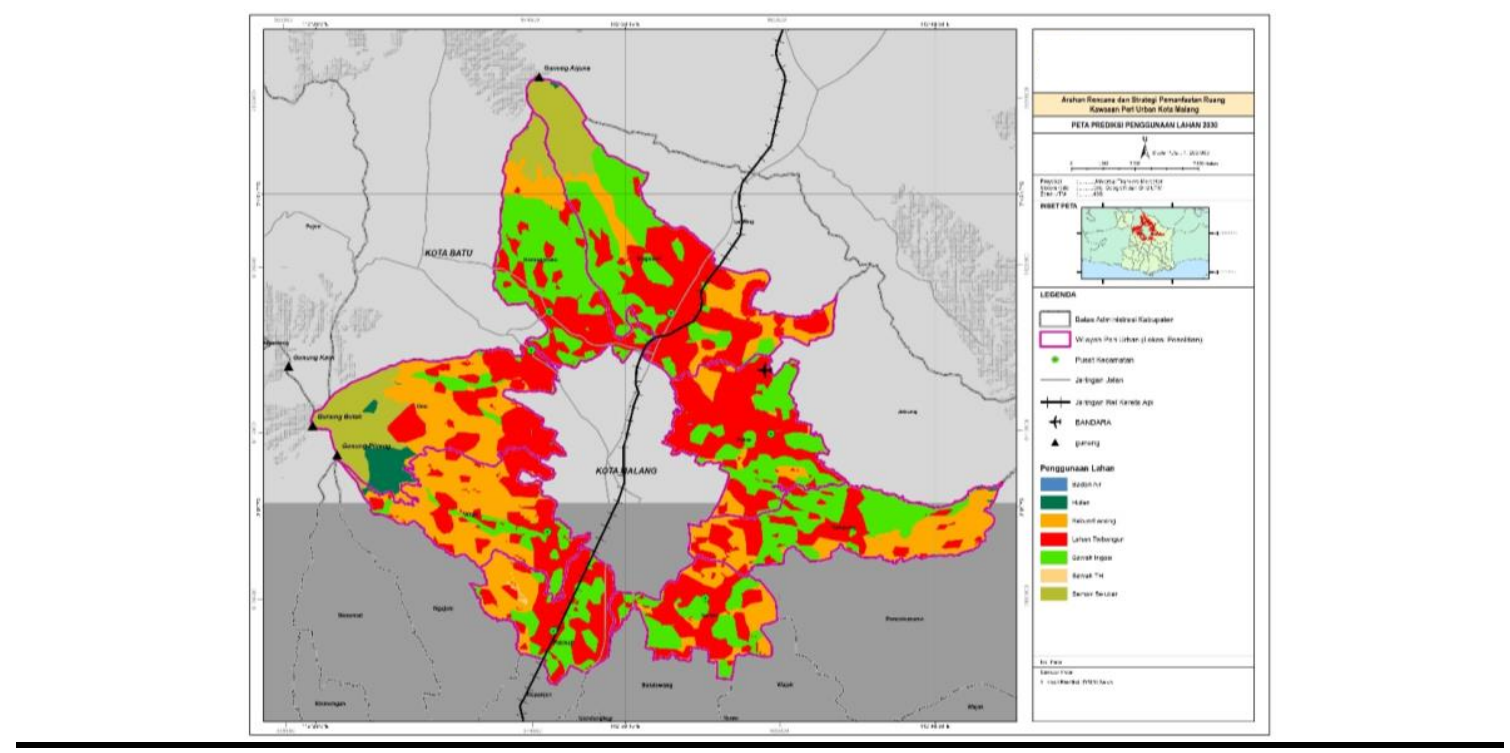

Gambar 10. Peta Prediksi Penggunaan Lahan Wilayah Peri Urban Tahun 2030

\section{Evaluasi Keselarasan Penggunaan Lahan 2030 dengan RTRW}

Rencana tata ruang wilayah Kabupaten Malang tahun 2010 - 2030 yang telah disahkan menjadi peraturan daerah mengarahkan distribusi pembangunan kedalam 6 (enam) wilayah pengembangan. Wilayah peri urban masuk kedalam Wilayah Pengembangan I lingkar Kota Malang. Wilayah ini memiliki tingkat pertumbuhan yang lebih tinggi dibandingkan wilayah pengembangan lainnya. Alokasi penggunaan lahan wilayah peri urban menurut RTRW yang terbesar adalah untuk lahan terbangun yang meliputi sarana prasarana wilayah, permukiman, industri, militer dan perdagangan jasa mencapai 23.692 ha pada tahun 2030, dengan selisih sekitar 3.069 ha dari hasil analisis prediksi penggunaan lahan. Perbandingan luasan lahan dalam RTRW dan hasil prediksi tersaji pada Gambar 11.

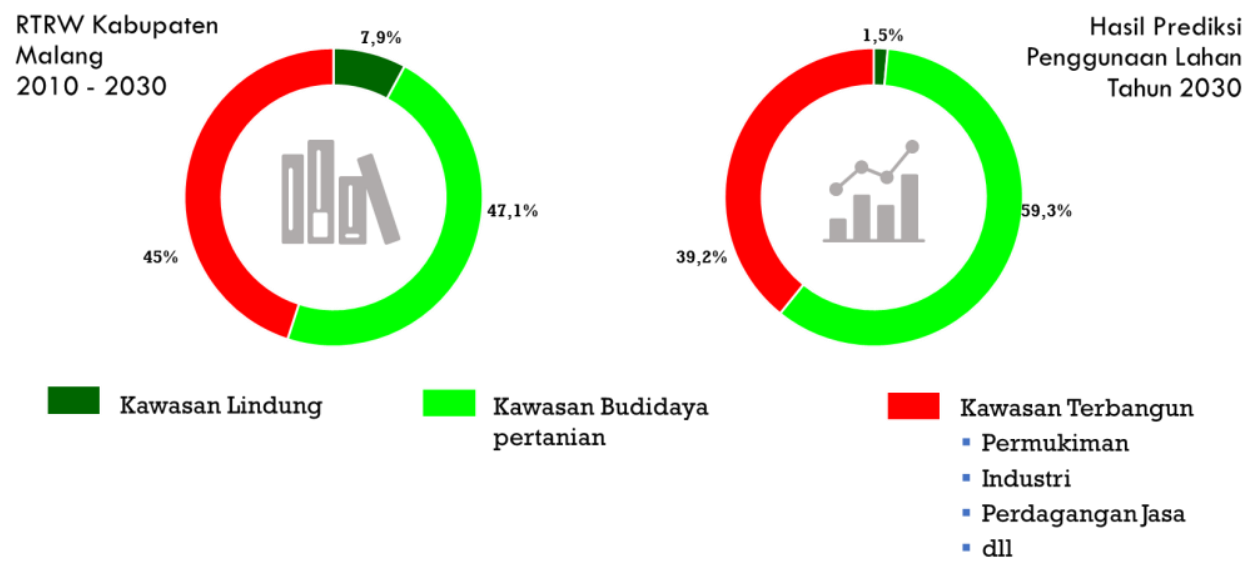

Gambar 11. Persentase Penggunaan Lahan RTRW dan Hasil Prediksi 2030

Perbedaan rencana penggunaan lahan dan prediksi tahun 2030 cukup signifikan. Hasil prediksi menunjukkan luasan kawasan lindung yang semakin sedikit terkonversi menjadi lahan pertanian. Sementara dalam RTRW luasan kawasan lindung harus dipertahankan. Kehilangan fungsi hutan tersebut terdiri dari berkurangnya kawasan hutan lindung dan hutan konservasi. 
Kondisi ini mengancam fungsi hutan sebagai daerah resapan air yang menaungi dan melindungi wilayah-wilayah di bawahnya. Hasil analisis potensi ketidakselarasan penggunaan lahan tahun 2030 dengan rencana pola ruang 2010 - 2030 disajikan pada Tabel 6.

Tabel 6. Potensi ketidakselarasan penggunaan lahan 2030 dengan RTRW

\begin{tabular}{clcc}
\hline \multirow{2}{*}{ No } & \multicolumn{1}{c}{ Potensi Ketidakselarasan } & ha & Luas \\
\cline { 3 - 4 } & \multicolumn{1}{c}{ Kawasan Hutan Lindung $\rightarrow$ Kebun/Tegalan } & 1.338 & 2,5 \\
2 & Kawasan Hutan Lindung $\rightarrow$ Semak Belukar \\
3 & $\begin{array}{l}\text { Kawasan Peruntukan Pertanian Lahan Kering - kawasan } \\
\text { terbangun }\end{array}$ & 4.149 & 7,9 \\
4 & $\begin{array}{l}\text { Kawasan Peruntukan Pertanian Lahan Basah } \rightarrow \\
\text { Kebun/Ladang/tegalan }\end{array}$ & 5.258 & 10 \\
5 & $\begin{array}{l}\text { Kawasan Peruntukan Pertanian Lahan Basah } \rightarrow \text { kawasan } \\
\text { terbangun }\end{array}$ & 64 & 0,1 \\
\hline & $\quad$ Jumlah & 1.141 & 2,2 \\
\hline
\end{tabular}

Tabel 6 menunjukkan bahwa potensi ketidakselarasan RTRW dengan prediksi penggunaan lahan tahun 2030 sebesar 11.950 ha atau 22,7\% dari total luas wilayah peri urban. Potensi ketidakselarasan dari peruntukan kawasan pertanian lahan kering menjadi kawasan terbangun memiliki nilai yang paling tinggi, yakni $10 \%$. Kecenderungan alih fungsi lahan pertanian menjadi kawasan terbangun menjadi fenomena yang terjadi secara terus menerus di wilayah peri urban. Pola umum yang terjadi adalah dari kawasan hutan menjadi lahan pertanian kemudian menjadi kawasan terbangun. Adapula dari pertanian lahan basah (sawah) menjadi pertanian lahan kering dan kemudian menjadi kawasan permukiman. Hal ini tentunya menjadi catatan bagi pemerintah daerah untuk mengantisipasi perubahan - perubahan penggunaan lahan yang akan terjadi di wilayah peri urban. Sebagaimana yang telah diatur dalam undang - undang tata ruang, kawasan hutan merupakan suatu wilayah tertentu yang ditunjuk dan/atau ditetapkan oleh pemerintah untuk dipertahankan keberadaannya. Sebaran spasial dari potensi ketidakselarasan penggunaan lahan tahun 2030 dengan RTRW dapat dilihat pada Gambar 12.

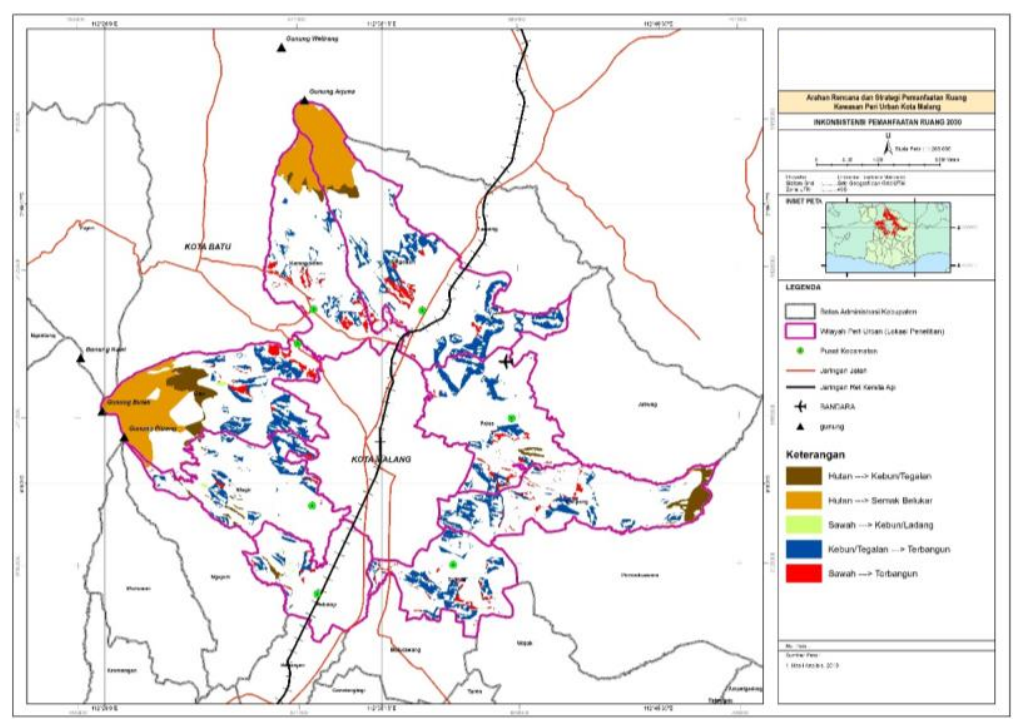

Gambar 12. Potensi ketidakselarasan prediksi penggunaan lahan tahun 2030 dengan RTRW

Potensi ketidakselarasan penggunaan lahan 2030 dengan RTRW terbesar berada di Kecamatan Dau dengan persentase mencapai 45\%. Hal ini disebabkan hasil prediksi menunjukkan adanya penyusutan lahan hutan dan berganti menjadi penggunaan pertanian lahan 
kering serta semak belukar. Hasil prediksi juga menunjukkan ada kecenderungan lahan pertanian berubah fungsi menjadi kawasan permukiman. Kecamatan Singosari juga memiliki potensi ketidakselarasan yang cukup tinggi, yaitu sekitar 30\%. Persentase konsistensi penggunaan lahan wilayah peri urban hasil prediksi 2030 dengan RTRW Kabupaten Malang 2010 - 2030 tersaji pada Gambar 13. Formulasi tata spasial dan aplikasinya kalah cepat berpacu dengan proses perubahan spasial yang ada di lapangan, karena permasalahan yang berkaitan dengan aplikasi peraturan tidak dilaksanakan secara konsisten dan konsekuen (Yunus, 2005).

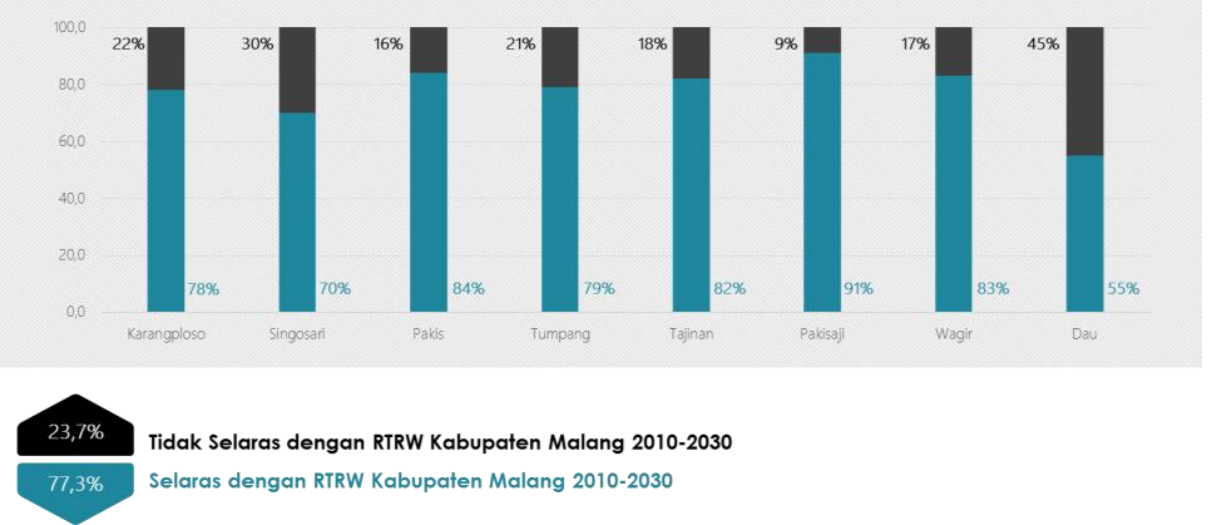

Gambar 13. Konsistensi Penggunaan Lahan Prediksi Tahun 2030 dengan RTRW per Kecamatan

Wilayah peri urban merupakan wilayah yang strategis dan cepat berkembang, sehingga densifikasi kawasan terbangun akan semakin meningkat jika tidak dikendalikan. Hudalah dan Firman (2012) menyatakan bahwa urbanisasi di wilayah peri urban menjadi tidak terkendali karena kapasitas perencanaan tidak mampu menangkap kompleksitas pembangunan yang ada. Disadari atau tidak, telah terjadi suatu gejala dimana pertimbangan kenyamanan dan sosioekologis dikorbankan. Untuk itu, dibutuhkan suatu inovasi pengaturan pemanfaatan ruang di wilayah peri urban guna menciptakan pertumbuhan dan stabilitas ekonomi lokal, terintegrasi dengan sistem kota, layak huni, berkeadilan sosial, berwawasan budaya dan lingkungan.

\section{KESIMPULAN}

Hasil tumpang tindih peta penggunaan lahan tahun 2008, 2013 dan 2018 menunjukkan luasan lahan terbangun memiliki trend naik sementara luasan kawasan hutan dan lahan pertanian mengalami penurunan. Selama 10 tahun, perkembangan lahan terbangun mengalami kenaikan sebesar $12 \%$. Aspek kependudukan menjadi faktor penting yang mempengaruhi perubahan penggunaan lahan suatu wilayah. Kecamatan Singosari memiliki jumlah penduduk terbanyak pada tahun 2010 sebesar 165.851 jiwa dan bertambah menjadi 185.807 jiwa pada tahun 2018. Pertumbuhan penduduk yang tinggi justru terjadi di Kecamatan Pakis. Pada tahun 2010 Kecamatan Pakis berpenduduk 136.267 jiwa dan naik menjadi 164.377 jiwa pada tahun 2018.

Hingga tahun 2033 diprediksi penggunaan lahan terbangun seluas 26.456 ha yang artinya mengalami kenaikan sebesar 17.686 ha $(33,6 \%)$ dari luas lahan terbangun eksisting tahun 2018. Sementara itu, hasil prediksi juga menunjukkan luasan pertanian lahan basah (padi sawah) mengalami penyusutan menjadi $12.787 \mathrm{ha}$.

Luas alokasi ruang untuk penggunaan lahan terbangun mencapai 23.692 ha pada tahun 2030. Terdapat selisih sekitar 3.069 ha dengan hasil analisis prediksi penggunaan lahan. Besarnya lahan terbangun yang direncanakan dalam RTRW tersebut untuk menyiapkan Kecamatan Singosari sebagai kawasan industri terpadu. Potensi ketidakselarasan RTRW dengan prediksi penggunaan lahan tahun 2030 sebesar 11.950 ha atau $22,7 \%$ dari total luas wilayah peri 
urban. Potensi ketidakselarasan dari peruntukan kawasan pertanian lahan kering menjadi kawasan terbangun memiliki nilai yang paling tinggi, yaitu $10 \%$.

\section{DAFTAR PUSTAKA}

Arifien Y. 2012. Pola Transformasi Spasial Dalam Penataan Ruang Kawasan Jabodetabek [disertasi]. Bogor (ID): Institut Pertanian Bogor.

As-syakur AR, Suarna IW, Adnyana IWS, Rusna IW, Laksmiwati IAA, dan Diara IW. 2010. Studi Perubahan Penggunaan Lahan Di DAS Badung. Jurnal Bumi Lestari. 10 (2): 200-207.

[BPS] Badan Pusat Statistik Kabupaten Malang. 2013. Kabupaten Malang Dalam Angka Tahun 2013. Malang (ID): Badan Pusat Statistik Kabupaten Malang.

[BPS] Badan Pusat Statistik Kabupaten Malang. 2014. Kabupaten Malang Dalam Angka Tahun 2014. Malang (ID): Badan Pusat Statistik Kabupaten Malang.

[BPS] Badan Pusat Statistik Kabupaten Malang. 2015. Kabupaten Malang Dalam Angka Tahun 2015. Malang (ID): Badan Pusat Statistik Kabupaten Malang.

[BPS] Badan Pusat Statistik Kabupaten Malang. 2016. Kabupaten Malang Dalam Angka Tahun 2016. Malang (ID): Badan Pusat Statistik Kabupaten Malang.

[BPS] Badan Pusat Statistik Kabupaten Malang. 2017. Kabupaten Malang Dalam Angka Tahun 2017. Malang (ID): Badan Pusat Statistik Kabupaten Malang.

[BPS] Badan Pusat Statistik Kota Malang. 2017. Kota Malang Dalam Angka Tahun 2017. Malang (ID): Badan Pusat Statistik Kota Malang

Deng JS, Wang K, Hong Y, and Qi JG. 2009. Spatio Temporal Dynamics and Evolution of Land Use Change and Landscape Pattern in Response to Rapid Urbanization. Landscape and Urban Planning 92: 187-198.

El-Hallaq MA and Habboub MO. 2015. Using Cellular automata-Markov Analysis and Multi Criteria Evaluation for Predicting the Shape of the Dead Sea. Scienctific Research Publishing 4: 83-95.

Hudalah D and Firman T. 2012. Beyond Property: Industrial estates and post-suburban transformation in Jakarta Metropolitan Region. Cities 29: 40-48.

Janthy TH, Santun R.P Sitorus, Ernan Rustiadi, dan Machfud. 2013. Dinamika Pertumbuhan dan Status Keberlanjutan Kawasan Permukiman di Pinggiran Kota Wilayah Metropolitan Jakarta. Globe 15 (1): 93 100.

Lopez E, Bocco G, Mendoza M, and Duhau E. 2001. Predicting land-cover and landuse change in the urban fringe: A case in Morelia city, Mexico. Landscape And Urban Planning 55: 271-285.

Muta'ali L. 1998. Transformasi Spasial Perkotaan dan Segitiga Pertumbuhan Ekonomi. Paper disampaikan dalam Diskusi Insidentil tentang Transformasi wilayah. Yogyakarta (ID): Universitas Gadjah Mada.

Pradoto W dan Mahendra YI. 2016. Transformasi Spasial di Kawasan Peri Urban Kota Malang. Jurnal Pembangunan Wilayah dan Kota 12 (1): 112-126.

Rustiadi E, Saefulhakim S, dan Panuju DR. 2011. Perencanaan dan Pengembangan Wilayah. Jakarta (ID): Cresspent Press dan Yayasan Obor Indonesia.

Sitorus SRP, Leonataris C, dan Panuju DR. 2012. Analisis Pola Perubahan Penggunaan Lahan dan Perkembangan Wilayah di Kota Bekasi, Provinsi Jawa Barat. Jurnal Tanah dan Lingkungan. 14 (1): 21-28.

Sitorus SRP. 2017. Perencanaan Penggunaan Lahan. Bogor (ID): IPB Press.

Yudarwati R, Sitorus SRP, and Munibah K. 2016. Controlling Policy Of Land Use Change Using Markov-Cellular Automata In Cianjur Regency. Tataloka 18 (4): 211 - 221.

Yunus HS. 2005. Klasifikasi Kota. Yogyakarta (ID): Pustaka Pelajar.

Zhang B, Yao Y, Cheng W, Zhou C, Lu Z, and Chen X. 2002. Human-Induced Changes to Biodiversity and Alpine Pasteurland in the Bayanbulak Region of the East Tianshan Mountains. Mountain Research and Development $22(4): 1-7$. 